\title{
BONE FLOUR FROM SUCKERMOUTH FISH (Pterygoplichthys pardalis) AND TILAPIA FISH (Oreochromis mossambicus)
}

\author{
Riris Lindiawati Puspitasari ${ }^{*}$, Femilda Khavidhar ${ }^{2}$, Kintan Ayu Gustiananda ${ }^{3}$, \\ Muhammad Alwan ${ }^{4}$, Puspitha Cahaya Ayu Widyanto ${ }^{5}$, Siti Anisah ${ }^{6}$, Ainul Haq ${ }^{7}$ \\ ${ }^{1-6}$ Biology Department, Science and Technology Faculty, University of Al Azhar Indonesia, Jl. \\ Sisingamangaraja Kebayoran Baru, Jakarta 12110 \\ ${ }^{7}$ Industrial Engineering, Industrial Technology Faculty, Gunadarma University, Jl. Margonda Raya No. \\ 100 Depok, Jawa Barat 16424 \\ *Corresponding author: lindiawatiriris@gmail.com
}

\begin{abstract}
Fish is often used as a protein source in food. Fish has good nutritional content for the body such as protein, vitamin, mineral, and unsaturated fatty acid. Pterygoplichthys pardalis and Oreochromis mossambicus are some of the local fishes that are frequently found in a river in Indonesia, also Asia. People use their meat as food. Unfortunately, people do not use fishbones. In this research, we processed the fishbone into flour which could be used as food or supplement. Fishes were collected from the breeder in January to May 2019. Bone processing methods carried out by separation of fish meat and bone, continued with bone flour processing using oven and grinder. According to the proximate analysis revealed that $P$. pardalis bone flour contained $25.047 \%$ protein, $10.478 \%$ fat, $0.656 \%$ water, $59.463 \%$ ash, and $4.353 \%$ carbohydrate. $O$. mossambicus also contained $36.929 \%$ protein, $11.942 \%$ fat, $2.575 \%$ water, $45.721 \%$ ash, and $2.833 \%$ carbohydrate. From these results, protein in $P$. pardalis gave a higher value than $O$. mossambicus. Bone flour from both fishes showed a smooth texture and whitish color. Bone flour from fish has good prospects to be developed to get complete analysis in food technology. Bone flour from suckermouth fish played important role in aquaculture and supported the river biodiversity.
\end{abstract}

Keywords: bone flour, Pterygoplichthys pardalis, Oreochromis mossambicus, protein, aquaculture

\section{INTRODUCTION}

Indonesia's territorial waters are rich in fish diversity. The wealth of fish both at sea and in freshwater waters has not been utilized optimally. The community's weak ability to process fishery products is still very low, due to a lack of innovation in product development. The public view of one type of fish, for example, the Pterygoplichthys pardalis is still low. This is because $P$. pardalis look creepy physically and have hard heads, skin, and scales (Tunjungsari 2007).

Fish is a food ingredient that is often consumed by people. In general, spoilage of fish occurs very quickly compared to other food ingredients. Bacteria and chemical content in fish cause the decay process to 
accelerate. Fish processing innovation is needed to extend the shelf life of fish products, one of which is processing fish into shredded fish (Kusumayanti et al., 2011 and El Shehawy et al., 2016).

One of the fish processing waste is fishbones. Fishbones cannot be used properly by the community. The content of fishbones consists of organic and inorganic (mineral) compounds (Petenuci et al., 2010). One of the aquatic products that are rich in calcium is fish, especially the bones (Putranto et al., 2015). Fishbone could be processed into bone flour and used as supplements and drugs to prevent osteoporosis (Jiancong et al., 2010). Bone can also be used as food, one of which is dry noodles (Mulia 2004).

The objective of this research was to utilize $P . \quad$ pardalis bone waste and Oreochromis mossambicus fishbones as flour. Also, we determined the content of fishbone with proximate analysis. Fish wss a food source of high-value protein, vitamins, minerals, and unsaturated fatty acids. Fish with high nutritional content include $P$. pardalis (KKP Research Center for Product Processing and Biotechnology 2013). P. pardalis came from Central and South America which were introduced into Indonesian waters and commonly found in Indonesia's freshwater waters (Hariyandati 2015, Rao et al., 2017).
This fish is widely used as an aquarium cleaner that we usually see, called the common pleco, a species of Hypostomus plecostomus or P. pardalis (Sinaga 2013). According to Dhika (2013), they able to live in any environment. The fish can live in ponds, ditches, and even environments that have been polluted with waste, although this is not a problem for it. The many types of food, such as dumplings, and meatballs, have made some people use $P$. pardalis raw material. Also, meat and fishbones can be processed into several food products, namely flour and shredded. Fish flour is a source of animal protein and minerals needed in the composition of animal feed. Fish flour is a low water content product obtained from fish grinding. Relatively high protein content composed of complex essential amino acids (methionine and lysine) and minerals ( $\mathrm{Ca}$ and $\mathrm{P}$, and vitamin B12). The chemical composition of fish meat can vary depending on fish species, age level, habitat, and eating habits these fish. Based on the results of research by Chaidir (2001), the nutritional content of $P$. pardalis in the Cirata pond, the ash content of $1.01 \%$, a fat content of $1.23 \%$, protein content of $19.71 \%$, and carbohydrate content $1 \%$. With this protein content, these fishes can be classified in the medium protein fish group. 


\section{MATERIALS AND METHODS}

The object of this research were $P$. pardalis and $O$. mossambicus obtained from the breeder. The research was conducted from January to May 2019. The processing into product was carried out at the Green House and Chemical Laboratory of Al Azhar Indonesia University, South Jakarta. The tools used in this research include High Density Polyethylene (HDPE) plastic, knives, gloves, water bath, analytical balance, pressure cooker, aluminum foil, thermometer, grinder, stove, pot, and oven, and the materials needed in this study about 28 fishes in one aquarium. Five tilapia fishes were preserved as stocks. Two fishes were processed to obtain meat and bones. All of two species fishes were then analyzed the content of proximate. This pretreatment was run for 7 days in lab.

The research carried out consisted of separating the meat and fishbones, making the floss, and proximate analysis of fish flour. The fish are surgically removed first, then the meat, bones, and skin are separated. For the manufacture of fishbone flour, it is used with a mass weight of 200.04 gr, while tilapia fish is made into the flour with a mass weight of 588.04 gr, then the weighed meat and bones are stored in the refrigerator.

\section{Making Fishbone Flour}

The processing of fishbone flour is based on the implementation method used by Putranto et al., (2015) on Belida fish with a modified method, namely without soaking fishbones with $\mathrm{NaOH}$ and boiling modification using lime leaves. First, the fishbones are washed thoroughly under running water and drained. Then the bones are boiled with water at $80{ }^{\circ} \mathrm{C}$ for 30 minutes using a water bath so that the remaining meat is easier to clean. The bones are washed again, drained, and weighed as much as $200 \mathrm{gr}$ for one serving. Each portion is softened using a pressure cooker for 2 hours plus a few lime leaves to reduce the fishbone smell. After that, the bones are boiled again in 2 liters of water at $100{ }^{0} \mathrm{C}$ for 30 minutes with two repetitions. The water is replaced with a new one every time the boiling process changes, then it is drained. Fishbones were oven-dried for 48 hours at a temperature of 65 ${ }^{0} \mathrm{C}$. Finally, mash the fishbones using a coffee grinder until it becomes flour and sieved using a flour sieve. The analysis of this study included the proximate composition (fat content, protein content, moisture content, ash content, carbohydrate) by sending 20 grams each of the samples to the laboratory. The fat content analysis used the Soxhlet method. Analysis of protein content using the Kjeldahl method. Analysis of water content and ash 
content using the Gravimetric method. The

carbohydrate analysis is calculated by

difference.

\section{RESULTS AND DISCUSSION}

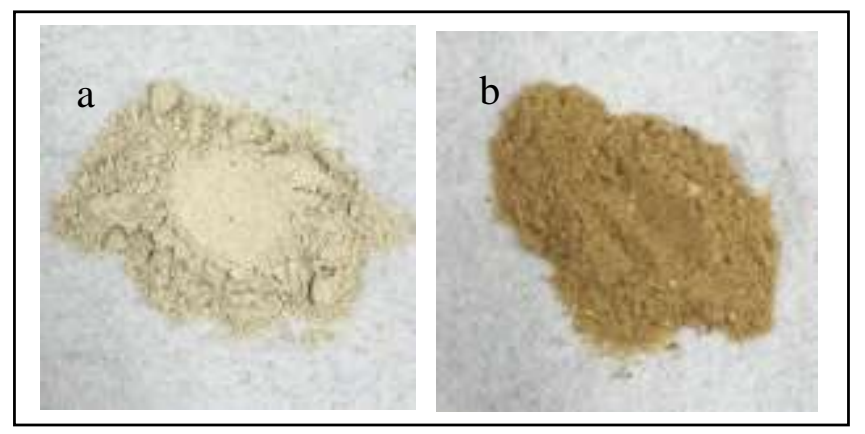

Fig.1. Results of fishbone flour a. P. pardalis and b. O. mossambicus

The characteristics of the two bone flour products are as follows:

Table 1. Characteristics of fishbone flour

\begin{tabular}{lll}
\hline & P. pardalis & O. mossambicus \\
\hline Color & White & Brown \\
& yellowish & yellowish \\
Smell & Fishy & Fishy \\
Texture & Smooth & Rough \\
\hline
\end{tabular}

The results of proximate testing conducted as follows:

Table 2. The results of testing the bone flour content

P.pardalis (\%) O. mossambicus (\%)

\begin{tabular}{lcc}
\hline Protein & 25.054 & 36.929 \\
Fat & 10.478 & 11.942 \\
Water & 0.656 & 2.575 \\
Ash & 59.463 & 45.721 \\
Carbohydrate & 4.353 & 2.833 \\
\hline
\end{tabular}

Fishbone is a waste that is commonly found in the fishing industry and many of compounds and inorganic compounds. Bone which have not been properly processed. flour is a product that has raw materials from According to Putranto 2015 and Amitha et al., fishbones, including the spine, smooth spines, 
tail, and skull bones of the fish. The results of the prototype fishbone flour produced were two kinds of fishbone flour derived from two different types of fish, $P$. pardalis and $O$. mossambicus.

The differences in the characteristics of the two fishbone flour products can be seen from the differences in the texture and size of the bones which are processed into flour. The dry weight of the broom fish bone flour produced was 93.35 gram from 315.15 gram of $P$. pardalis fishbones, and 80.88 gram from 588.84 gram of $O$. mossambicus fishbones. From the two prototypes, the $P$. pardalis fishbone flour product experienced a weight loss of $29.62 \%$ from the initial weight, and the O. mossambicus fishbone flour product experienced a weight loss of $13.73 \%$ from the initial weight. Weight loss occured due to the curing and drying processes. Curing is a seasoning process that aims to preserve and improve the aroma, taste, and texture of processed ingredients. Meanwhile, drying aimed to reduce water content in food processed materials by using heat energy. Reduced moisture content could affect the characteristics and dry weight of the processed product. Drying could be done in various ways, such as drying, oven, and other types of dryers (Septiawan, 2018).
In the results of the proximate test, it showed from the above results that the protein content of $P$. pardalis fishbone flour obtained was quite low about $25.054 \%$, compared to the protein content of $O$. mossambicus bone flour revealed in $36.929 \%$. Protein contained in bones are generally categorized into stromal protein. This stromal protein is resistant to acidic and alkaline solutions. The fat content of $P$. pardalis bone flour was lower than $O$. mossambicus. Low-fat content made the quality relatively more stable and not easily damaged. Abelti 2017 also stated that in tilapia fish, monounsaturated fatty acids constituted the largest proportion of total unsaturated fatty acids in both sexes. Meanwhile, high levels of fat can cause the flour to have a fish taste and cause oxidative rancidity as a result of fat oxidation (Kusumaningrum et al., 2016).

The water content of $O$. mossambicus bone flour was higher than $P$. pardalis. The basic material of $P$. pardalis fishbones had a relatively small chance of damage or decay. While the basic material of O. mossambicus fishbones which contained higher water will have a relatively large chance of damage. This was because the content of the water balance in the base material fish determined the acceptability of the material. Low water content made the bone flour more stable at room temperature. Besides, low water content 
affected resistance to microbial and bacterial attack (Kusumaningrum et al., 2016).

The ash content of the $P$. pardalis fishbone flour was much higher than $O$. mossambicus. Ash content analysis aims to determine the total ash content and determine the content of each mineral contained in the fishbone flour. The ash content in food showed the amount of inorganic material remaining after the organic matter was digested (Putranto et al., 2015). Moreover, the calcium content that found in bone powder from yellowfin tuna were abundant in calcium and therefor suitable for natural calcium source (Nemati et al., 2017). The carbohydrate content of $P$. pardalis fishbone flour was higher than that of $O$. mossambicus. The carbohydrate content by difference is determined from the result of a $100 \%$ reduction in water content, ash content, fat content, and protein content. So that carbohydrate content depended on the reducing factor (Putra et al., 2015).

\section{CONCLUSIONS}

Based on the results of the research, the $P$. pardalis bone flour content about $25 \%$ protein, $10 \%$ fat, $4 \%$ carbohydrate, $59 \%$ ash, and $0.6 \%$ water. In O. mossambicus, there were $36 \%$ protein, $11 \%$ fat, $2 \%$ carbohydrate, $45 \%$ ash, and $2 \%$ water.

\section{ACKNOWLEDGMENT}

Thank you to Al Azhar Indonesia University for providing project funds through the internal research grant, so that this research can be carried out well.

\section{REFERENCES}

Abelti, A.L. (2017). Minerals Content and Fatty Acids Profile of Nile Tilapia (Oreochromis niloticus) Fillet from Lake Zeway: Effect of Endogenous Factors. J. Nutr. Food Sci. doi: 10.4172/2155-9600.1000574.

Amitha, Raju, C.V., Lakshmisha, I.P., Arun Kumar, A., Sarojini, A., Gajendra, and Jag Pal. (2019). Nutritional Composition of Fish Bone Powder Extracted from Three different Fish Filleting Waste Boiling with Water and an Alkaline Media. Int. J. Curr. Microbiol. App. Sci. 8(2): 2942-2948.

Balai Besar Riset Pengolahan Produk dan Bioteknologi KKP. (2013). Data Base Nilai Gizi Ikan. www.bbp4b.litbang.kkp.go.id/nilaigizi l. (Diakses 28 Desember 2019).

Chaidir A. (2001). Pengaruh Pencucian Daging Lumat (Minced fish) Ikan Sapu-sapu (Hypostosmus sp) terhadap kualitas minced fish dalam pembuatan bakso ikan [Skripsi]. Bogor: Program Studi Teknologi Hasil Perikanan, Fakultas Perikanan dan Ilmu Kelautan, IPB.

Dhika, L.R. (2013). Kandungan Logam Berat Kadmium (Cd) dalam Daging Ikan Sapu-sapu (Pterygoplichthys pardalis) di Sungai Ciliwung. IPB Repository. (Online). http://repository.ipb.ac.id/handle/1234 56789/64359. (Diakses 28 Desember 2018). 
El Shehawy, S.M., Gab-Alla, A.A., Mutwally, H.M.A. (2016). Proximate and Elemental Composition of Important Fish Species in Makkah Central Fish Market, Saudi Arabia. Food and Nutrition Sciences. 7: 429-43.

Fachruddin, L. (1997). Membuat Aneka Dendeng. Kanisius, Yogyakarta.

Hariyandati A. (2015). Aspek Reproduksi Ikan Sapu-Sapu (Pterygoplichthys pardalis) Di Sungai Ciliwung, Kebun Raya Bogor [Skripsi]. Bogor: Departemen Manajemen Sumberdaya Perairan, Fakultas Perikanan Dan Ilmu Kelautan, IPB.

Ismail, A. M., \& Putra, D. E. (2017). Inovasi Pembuatan Abon Ikan Cakalang Dengan Penambahan Jantung Pisang. Agritech, 45-54.

Kusumaningrum, I., Sutono, D., \& Pamungkas, B. F. (2016). Pemanfaatan Tulang Ikan Belida Sebagai Tepung Sumber Kalsium Dengan Metode Alkali, 19(2), 148-155.

Kusumayanti, H. Astuti, W. Broto, W,R,T,D. (2011). Inovasi Pembuatan Abon Ikan Sebagai Salah Satu Teknologi Pengawetan Ikan. Gema Teknologi. 16 (3).

Nemati, M., Huda, N., Ariffin, F. (2017). Development of calcium supplement from fish bone wastes of yellowfin tuna (Thunnus albacares) and characterization of nutritional quality. Int. Food Res. J. 24(6): 2419-2426.
Petenuci, M.E., Stevanato, F.B, de Morais, D.R., Santos, L.P., de Souza, N.E., Visentainer, J.V. (2010). Composition and lipid stability of tilapia fishbone flour. Ciência e Agrotecnologia. 34 (5): 1279-1284.

Putranto, H. F. Asikin, A. N. Kusumaningrum I. (2015). Karakterisasi tepung tulang ikan belida (Chitala sp.) sebagai sumber kalsium dengan metode hidrolisis protein. Ziraa'ah. 40 (1): 1120.

Rao, R.K., Sunchu, V. 2017. A report on Pterygoplichthys pardalis Amazon sailfin suckermouth Catfishes in Freshwater tanks at Telangana state, India. International Journal of Fisheries and Aquatic Studies. 5(2): 249-254.

Septiawan, A. (2018). Pengaruh Ukuran Potongan Wortel (Daucus carota) terhadap Karakteristik dan Daya Absorpsi Hasil Pengeringan Wortel Kering. [Skripsi]. Universitas Lampung.

Supriatna, J. (2008). Melestarikan Alam Indonesia. Edisi Pertama. Jakarta: Yayasan Obor Indonesia.

Sinaga, R. (2013). Eksotis Ikan Sapu-Sapu. (Online) http://www.kompasiana.com. (Diakses 28 Desember 2019).

Tunjungsari, R. M. (2007). Pemanfaatan Ikan Sapu-sapu (Hyposarcus pardalis) Dalam Pembuatan Keripik Ikan [Skripsi]. Program Studi Teknologi Hasil Perikanan, Fakultas Perikanan Dan Ilmu Kelautan, IPB. 